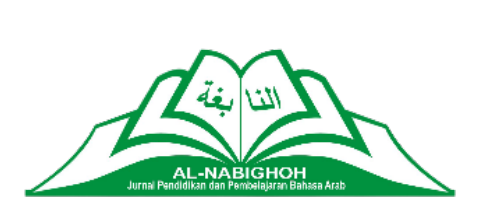

\title{
DESAIN DAN IMPLEMENTASI MOBILE LEARNING SEBAGAI UPAYA PENINGKATAN PEMBELAJARAN BAHASA ARAB DI MADRASAH ALIYAH
}

\author{
Khotijah', Ahmad Arifin ${ }^{2 *}$
}

${ }^{1}$ Institut Agama Islam Negeri Metro, Indonesia

${ }^{2}$ Institut Agama Islam Negeri Metro, Indonesia

\section{Article Info}

\section{Article History:}

Received: April 2021

Revised: June 2021

Accepted: June 2021

Published: June 2021

*Corresponding Author:

Name: Ahmad Arifin

Email: arifin@metrouniv.ac.id

\section{Abstract}

This research aims to design and implement mobile learning using Google Classroom and Quizizz applications for Arabic subjects for Madrasah Aliyah (Islamic Senior High School) students. This research is how to design, develop, and implement mobile learning in Arabic subjects among Madrasah Aliyah students. This learning media is made so that users can easily access an Arabic subject matter. The research target to be achieved is the existence of different exciting and easy-to-use learning media to increase student interest in learning and achievement in Arabic subjects. The research method used is experimental research with the design of this research model is one group pretest-posttest design. This research was conducted from January-August 2020. The subject of this study was Arabic language learning conducted at MA Nurul Ulum, Kota Gajah, and MA Ma'arif 9, Kota Gajah. The results show that the development of androidbased mobile learning still has not demonstrated results and effectiveness on learning outcomes but is effective in growing motivation and interest in learning Arabic.

Copyright (C) 2021, Khotijah, Ahmad Arifin This is an open-access article under the $\mathrm{CC}-\mathrm{BY}$-SA license

Keywords: $\quad$ Mobile Learning; Arabic; Islamic Senior High School.

\section{مستخلص البحث}

يهدف هذا البحث إلى تصميم وتنفيذ التعلم المتنقل باستخدام تطبيقات جوجل كلاس روم و قويزيز للمواد العربية لطلاب المدرسة الثانوية

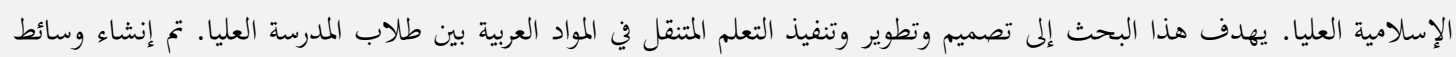
التعلم هذه بحيث يمكن للمستخدمين الوصول بسهولة إلى موضوع باللغة العربية. الهدف البحثي المراد تحقيقه هو وجود وسائط تعليمية

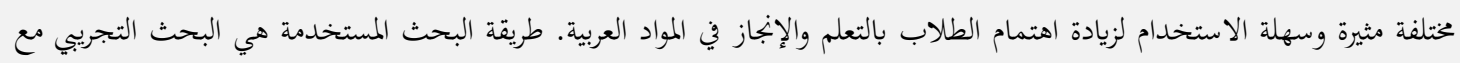

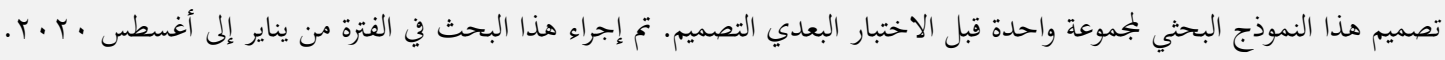

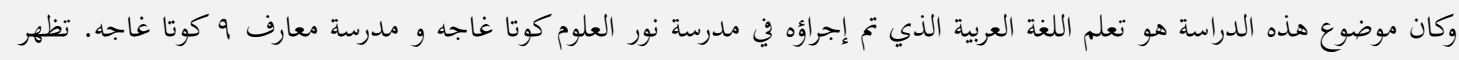
النتائج أن تطوير التعلم المتنقل المستند إلى أندرويد لم يظهر بعد نتائج وفعالية في نتائج التعلم ولكنه فعال في زيادة الحافز والاهتمام بتعلم اللغة العربية.

كلمات أساسية: التعليم الجوال؛ اللّغة العربية؛ المدرسة العالية. 


\section{Pendahuluan}

Revolusi industri 4.0 menggerus seluruh ranah kehidupan manusia, tidak terkecuali termasuk dunia pendidikan. Guru, siswa dan seluruh aspek yang terlibat di dalamnya tentu dituntut untuk dapat ikut terlibat dalam menghadapi gejolak arus tersebut. Penguasaan akan teknologi merupakan suatu keniscayaan bagi masyarakat pendidikan. Belum lagi dunia pendidikan termasuk di Indonesia juga terkena dampak dari wabah virus Covid-19, sehingga harus mengikuti ketentuan pemerintah yaitu belajar di rumah.

Meskipun pembelajaran tidak dilaksanakan dengan tatap muka seperti biasanya, Menteri Pendidikan dan kebudayaan memberikan ketentuan bahwa guru harus tetap membimbing peserta didik dengan media yang mendukung pembelajaran. ${ }^{1}$ Menjadi suatu keharusan bagi insan pendidikan untuk paling tidak menguasai dasar-dasar dalam dunia teknologi informasi. Sehingga diharapkan pembelajaran daring (dalam jaringan) yang dilaksanakan dapat berjalan dengan lancar tanpa ada hambatan berarti.

Pembelajaran daring tentu tidak akan dapat terlaksana tanpa adanya media. Terdapat banyak media yang dapat memfasilitasi pembelajaran daring, mulai dari yang berbayar hingga gratis. Efisiensi penggunaan tentu perlu dipertimbangkan, baik waktu dan kerumitan pembuatan atau pengaplikasian media tersebut. Pendidik dituntut untuk lihai dalam mengemas materi pembelajaran yang akan diajarkan secara tanpa tatap muka, guna tercapainya pembelajaran yang diharapkan. Lahirnya mobile learning dapat mendukung konsep pendidikan sepanjang hayat karena mobile learning bersifat dapat berkembang secara terus menerus dan dapat digunakan di segala kesempatan. Mobile learning adalah salah satu konsep perpindahan dari sumber belajar yang dahulu bersifat cetak menjadi sumber belajar digital tanpa mengurangi fungsi dan isi dari pembelajaran itu sendiri.

Adapun mobile learning (m-learning) merupakan salah satu dari sekian banyak model pembelajaran yang memungkinkan siswa memperoleh materi pembelajaran dimana pun dan kapan pun, dengan menggunakan teknologi seluler dan Internet. Karenanya unsur-unsur pembelajaran di dalamnya harus diatur dengan benar, dan interaksi antara berbagai elemen digabungkan secara efisien dan optimal sehingga pembelajaran berhasil. Selain itu, karakteristik mobile learning harus ditata, serta durasi waktu aplikasi harus direncanakan dengan baik di awal. Oleh karenanya, diperlukan wawasan yang lebih dalam tentang penelitian berbasis teori untuk lebih memahami dasar motivasi yang mengarahkan akademisi untuk mengadopsi elemen dan karakteristik pembelajaran seluler.

1 “Nadiem: Belajar Di Rumah Perlu Dibuat Prosedur Khusus," Republika Online, 21 Maret 2020, https://republika.co.id/share/q7hplp430. 
Peserta didik, guru, lingkungan, konten dan penilaian adalah elemen dasar dari pembelajaran seluler yang lengkap. ${ }^{2}$

Pembelajaran secara konvensional yang dilakukan secara monoton di dalam kelas memiliki banyak kekurangan seperti mudahnya siswa dihinggapi rasa bosan, keterbatasan akses lokasi belajar, waktu belajar yang terbatas, dan lain sebagainya. Mengingat era teknologi saat ini, seolah menjadi suatu hal yang wajib untuk mengkolaborasikan antara pembelajaran dengan teknologi. Kelemahan serta keterbatasan pembelajaran secara konvensional telah melahirkan ide pembelajaran dengan konsep baru dimana mendekat kepada pemanfaatan TIK. Dunia pendidikan telah mengenal sistem mobile learning yang mengacu kepada pemanfaatan teknologi belajar yang berbeda, dan membantu pembelajaran jarak jauh. Mobile learning mencakup model yang berbeda dari kelas konvensional dimana akan dikenalkan seperti web belajar, adanya ruang kelas virtual, dan pembelajaran yang dibantu komputer serta komunikasi digital. ${ }^{3}$

Sedangkan mempelajari bahasa bukanlah pekerjaan instan dengan sebuah panduan ringkas. Dibutuhkan berbagai keterampilan kompleks untuk dapat menguasainya. Ilmu bahasa dibagi menjadi dua klaster, yaitu linguistik murni dan linguistik terapan. Fonetik, fonologi, morfologis, sintaksis, dan semantis merupakan garapan bidang linguistik murni. Adapun linguistik terapan mencakup aktivitas menerjemahkan, pengajaran bahasa, dan leksikografi. Pada era berbasis media ini, kiprah pembelajaran dan pengajaran bahasa Arab terlihat redup sinarnya, hal ini disebabkan oleh matinya kreativitas guru dalam menguraikan pemecahan masalah serta berbagai problem fundamental yang membuat pembelajaran bahasa Arab yang kurang bergairah. ${ }^{4}$

Di dalam usaha mempelajari bahasa asing tentunya memerlukan berbagai aspek vital dalam mendukung keberhasilannya. Terdapat empat aspek urgen di dalam pembelajaran bahasa yang harus dikuasai. Keempat aspek keterampilan tersebut ialah: keterampilan menyimak (istima), keterampilan berbicara (muhadatsah), keterampilan membaca (qira'ah), serta keterampilan menulis (kitabah). ${ }^{5}$ Keempat keterampilan tersebut saling berkaitan dan saling mendukung satu dengan lainnya. oleh karenanya dibutuhkan kecakapan untuk dapat menguasai keempat keterampilan dari pembelajaran bahasa tersebut.

\footnotetext{
2 Fezile Ozdamli dan Nadire Cavus, "Basic Elements and Characteristics of Mobile Learning," Procedia - Social and Behavioral Sciences 28 (2011): 937-42, https://doi.org/10.1016/j.sbspro.2011.11.173.

${ }^{3}$ Mugi Praseptiawan, Dadan Sujana, dan Muhamad Djuanda, "Pengembangan Mobile Learning (M-Learning) STKIP Setiabudhi Sebagai Daya Dukung Pembelajaran Mahasiswa," Produktif : Jurnal IImiah $\begin{array}{lllll}\text { Pendidikan Teknologi } & \text { Informasi } & 2 & \text { (2018): }\end{array}$ https://journal.umtas.ac.id/index.php/produktif/article/view/212.

${ }^{4}$ Fathul Mujib dan Nailur Rahmawati, Metode Permainan-Permainan Edukatif Dalam Belajar Bahasa Arab (Yogyakarta: Diva Press, 2011), 5-6.

${ }^{5}$ Akhmad Sangid dan Mohammad Muhib, "Strategi Pembelajaran Muhadatsah," Tarling : Journal of Language Education 2, no. 1 (2018): 1-22, https://doi.org/10.24090/tarling.v2i1.2226.
} 
Pendengaran manusia di dalam mempelajari bahasa untuk dapat menguasai keterampilan mendengar (istima') yang dibutuhkan agar dapat memahami ide-ide pokok secara terperinci. ${ }^{6}$ Keterampilan lainnya yang juga dibutuhkan dalam menguasai bahasa asing adalah keterampilan membaca (qiraah). Selanjutnya, keterampilan membaca digunakan untuk dapat mengenali dan memahami isi dari tulisan baik dengan cara melafalkan maupun mencerna di dalam hati. ${ }^{7}$ Di dalam mempelajari bahasa tentunya tidak hanya dipelajari dari sisi lisan akan tetapi juga tulisan karena terkadang penulisan dan pelafalan memiliki ragam berbeda. Contohnya di dalam bahasa Arab memiliki huruf hijaiyah dalam penggunaannya diperlukan beberapa kaidah. Dalam mempelajari berbagai kaidah tersebut maka dibutuhkan keterampilan menulis (kitabah). ${ }^{8}$

Selain ketiga keterampilan tersebut, salah satu keterampilan dasar dalam menguasai bahasa asing adalah keterampilan berbicara atau muhadatsah. Penguasaan keterampilan berbicara ini diharapkan siswa mampu mengungkapkan artikulasi kata dengan tepat untuk dapat mengungkapkan pendapat mereka berupa ide, gagasan, perasaan, maupun keinginan mereka kepada mitra bicaranya. $^{9}$ Apabila peserta didik menguasainya, maka ia akan dapat berkomunikasi dengan lisan sesuai kriteria dan tata aturan sesuai dengan bahasa yang dipelajarinya.

Selain problematika linguistik, masalah juga datang dari non linguistik yang berarti timbulnya masalah di luar dari bahasa itu sendiri. Hal tersebut terlihat dari berbagai unsur. Pertama, kurangnya kompetensi pendidik sebagai guru Bahasa Arab, baik dari segi kompetensi pedagogik, profesionalisme, sisi personal, maupun sosialnya. Kedua, motivasi dari peserta didik yang dinilai kurang kuat untuk belajar Bahasa Arab. Ketiga, kurang relevannya materi ajar pada kebutuhan siswa. Keempat, kurangnya sarana dan prasarana yang memadai untuk menunjang belajar mengajar Bahasa Arab. ${ }^{10}$

Berbagai kendala muncul dalam pengoptimalan pembelajaran bahasa Arab. Alokasi waktu yang tersedia untuk pembelajaran Bahasa Arab yang ada di Madrasah Aliyah sangatlah terbatas sehingga mengakibatkan kurangnya minat

\footnotetext{
${ }^{6}$ Qomi Akid Jauhari, "Pembelajaran Maharah Istima Di Jurusan PBA UIN Maulana Malik Ibrahim Malang," Tarbiyatuna: Jurnal Pendidikan Ilmiah 3, no. $1 \quad$ (2018): 129, http://ejournal.kopertais4.or.id/mataraman/index.php/tarbiyatuna/article/view/3440.

7 Fredina Fransiska dan Zaim Elmubarok, "Efektivitas Metode Reading Guide Terhadap Keterampilan Membaca Bahasa Arab Siswa Kelas XI IPS MAN Demak," Lisanul Arab: Journal of Arabic Learning and Teaching 4, no. 1 (2015), https://journal.unnes.ac.id/sju/index.php/laa/article/view/7634.

${ }^{8}$ Zhul Fahmy Hasani, “Penerapan Metode Imla' Untuk Meningkatkan Keterampilan Menulis Siswa Kelas VIIC MTs Muhammadiyah 02 Pemalang," Lisanul Arab: Journal of Arabic Learning and Teaching 2, no. 1 (2013): 57-64, https://journal.unnes.ac.id/sju/index.php/laa/article/view/2564.

${ }^{9}$ Hastang Nur, "Penerapan Metode Muhadatsah Dalam Meningkatkan Hasil Belajar Maharah Kalam Peserta Didik," Lentera Pendidikan : Jurnal Ilmu Tarbiyah Dan Keguruan 20, no. 2 (2017): 177, https://doi.org/10.24252/Ip.2017v20n2i4.

10 Nandang Sarip Hidayat, "Problematika Pembelajaran Bahasa Arab," An-Nida' 37, no. 1 (2012): 82-88, http://ejournal.uin-suska.ac.id/index.php/Anida/article/view/315.
} 
siswa untuk belajar bahasa Arab. Penggunaan strategi pembelajaran, model pembelajaran, media pembelajaran yang menggunakan cara-cara lama sehingga kurang efektif dalam pembelajaran. Padahal proses pembelajaran akan efektif apabila peserta didik dilibatkan langsung di dalam sebuah kondisi sehingga ia mengalami pengalaman langsung di dalam pembelajaran tersebut bukan hanya duduk diam sedangkan pembelajaran terpusat pada guru. ${ }^{11}$

Perkembangan teknologi saat ini semakin canggih terlebih dengan dimasukinya era peradaban keempat atau yang disebut dengan -Revolusi Industri 4.0. Era baru ini menggunakan IT sebagai mayoritas basis kehidupannya. Salah satu produk yang digilai oleh manusia pada zaman ini adalah smartphone. Pengguna smartphone telah dimanjakan dengan berbagai fasilitas melalui aplikasi dan layanan super canggih, akan tetapi mayoritas pengguna justru memanfaatkannya hanya untuk berselancar, bersosial media, serta berbagai sarana hiburan lainnya. Pelajar sebagai mayoritas pemegang smartphone, terhitung sangat sedikit yang menggunakan smartphone untuk sarana pembelajaran (m-learning). Tidak diketahui berasal dari kurangnya inovasi guru atau memang kemalasan untuk memanfaatkan teknologi sebagai sarana pembelajaran. Padahal media pembelajaran berbasis smartphone android memiliki fleksibilitas penggunaannya yang bagus karena ia dapat digunakan kapan saja sesuai dengan kapasitas kecepatannya dalam belajar. ${ }^{12}$ Selain itu, berbagai macam aplikasi yang ada berbayar dan sulit diakses, oleh karenanya dibutuhkan media pembelajaran bahasa Arab yang dapat dengan mudah diakses oleh siswa.

Perangkat mobile seperti smartphone merupakan salah satu sarana untuk mendukung pembelajaran. Aktivitas pembelajaran dengan memanfaatkan perangkat mobile berupa smartphone disebut dengan mobile learning. ${ }^{13}$ Karakteristik dari penggunaan model pembelajaran ini adalah kemudahan dan sifat praktisnya yang dapat dibawa ke mana pun. Hal tersebut mengindikasikan bahwa informasi atau bahan ajar dikembangkan serta dikemas dengan apik melalui media yang selanjutnya disebut sebagai m-learning sehingga saat waktu pembelajaran tiba maka media ini dapat dimanfaatkan.

Pada penelitian ini didukung dengan berbagai penelitian-penelitian sebelumnya. Adapun penelitian yang relevan dengan penelitian ini adalah sebagai berikut: artikel jurnal Paramasastra yang ditulis oleh Hilman Septian dkk. dengan

11 Punaji Setyosari, "Menciptakan Pembelajaran Yang Efektif Dan Berkualitas," JINOTEP (Jurnal Inovasi Dan Teknologi Pembelajaran): Kajian Dan Riset Dalam Teknologi Pembelajaran 1, no. 1 (13 Desember 2017): 20-30, https://doi.org/10.17977/um031v1i12014p020.

12 Chetan B Ugale dkk., "Mobile Learning Application With Online Query Support," IJMTER (International Journal of Modern Trends in Engineering and Research) 02, no. 10 (2015): 239, https://www.ijmter.com/published-papers/volume-2/issue-10/mobile-learning-application-with-onlinequery-support/.

${ }^{13}$ Gufron Amirullah dan Restu Hardinata, "Pengembangan Mobile Learning Bagi Pembelajaran," JKKP (Jurnal Kesejahteraan Keluarga Dan Pendidikan) 4, no. $02 \quad$ (2017): 97, https://doi.org/10.21009/JKKP.042.07. 
judulnya: "Aplikasi Pengenalan Bahasa Arab-Inggris untuk Anak-Anak Berbasis Android" membahas mengenai progres pembuatan aplikasi yang dirancang untuk anak-anak berbasis android yang dapat mengenalkan kepada anak tentang pelajaran bahasa Arab dan Inggris. Di dalam penelitiannya, didapati bahwa aplikasi learning berbasis multimedia pada sistem operasi android merupakan solusi media pembelajaran yang aktif, interaktif, dan menyenangkan. Perolehan angka kuesioner sebesar 87,11\% maka aplikasi "layak" dan dapat didistribusikan. ${ }^{14}$

Sebuah jurnal dengan judul: "Implementasi dan Efektifitas Mobile Learning dengan Menggunakan Metode Synchronous dan Asynchronous Learning pada Pembelajaran Bahasa Inggris di Universitas Kuningan Berbasis Android" yang dikerjakan oleh Panji Novantara dan Heri Herwanto. Adapun hasil dari pembahasan penelitian yang dilakukan dari jurnal ini adalah pembuatan aplikasi media learning dengan bantuan tools software android studio tersebut mampu memudahkan pemahaman mahasiswa dalam mempelajari bahasa Inggris di Universitas Kuningan. 15

Sebuah jurnal karya Andri Kusuma dkk. Mengambil judul: "Pengembangan $M$ Learning Bahasa Arab Berbasis LTSA dengan Pendekatan ADDIE". Pada jurnal ini, peneliti berhasil mendapatkan hasil bahwa pembelajaran bahasa Arab di Madrasah Diniyah Takmiliyah Al-Qadar mengalami peningkatan dibantu dengan media pembelajaran interaktif berbasis LTSA. Berdasarkan evaluasi yang telah dilaksanakan dihasilkan angka 84,42\% sebagai angka uji kelayakan, dengan demikian aplikasi yang dikembangkan penulis layak untuk digunakan dalam proses pembelajaran dan dapat didistribusikan kepada wilayah yang lebih luas. ${ }^{16}$

Jurnal karya Widya Adhariyanty Rahayu dan Suastika Yulia Riska dengan penelitiannya yang diberikan judul: "Pengembangan Media Pembelajaran Game Kosakata Bahasa Inggris". Di dalam jurnal ini peneliti mengembangkan sebuah aplikasi game berbasis android yang dirancang untuk meningkatkan kemampuan menyerap kosakata bahasa Inggris secara menyenangkan dengan memanfaatkan smartphone dan internet bagi mahasiswa. ${ }^{17}$

Kecanggihan teknologi harus diimbangi dengan pemanfaatannya. Penulis menawarkan aplikasi mobile learning berupa perpaduan google classroom dan

${ }^{14}$ Hilman Septian, Eka Wahyu Hidayat, dan Alam Rahmatulloh, “Aplikasi Pengenalan Bahasa Arab dan Inggris untuk Anak-Anak Berbasis Android," Jurnal Online Informatika 2, no. 2 (2018): 71-78, https://doi.org/10.15575/join.v2i2.100.

${ }^{15}$ Panji Novantara, "Implementasi dan Efektifitas Mobile Learning dengan Menggunakan Metode Synchronous dan Asynchronous Learning pada Pembelajaran Bahasa Inggris di Universitas Kuningan Berbasis Android," Buffer Informatika 3, no. 1 (2017): 22-27, https://doi.org/10.25134/buffer.v3i1.932.

${ }^{16}$ Andri Kusuma Bhakti, Firdaus Solihin, dan Fitri Damayanti, "Pengembangan M-Learning Bahasa Arab Berbasis LTSA Dengan Pendekatan ADDIE," Jurnal Simantec 6, no. 2 (2017): 73-84, https://journal.trunojoyo.ac.id/simantec/article/view/3809.

${ }^{17}$ Widya Adhariyanty Rahayu dan Suastika Yulia Riska, “Developing English Vocabulary Learning Game," Jurnal Cakrawala Pendidikan 37, no. 1 (2018): 85-96, https://journal.uny.ac.id/index.php/cp/article/view/15965. 
quizizz untuk meningkatkan kemampuan dalam pembelajaran bahasa Arab berbasis android yang dirancang agar peserta didik dapat melakukan kegiatan pembelajaran secara interaktif, menarik, dan menyenangkan dengan memanfaatkan gadget yang ada dalam genggamannya. Berdasarkan penjelasan tersebut, peneliti merasa bahwa guru dan peserta didik membutuhkan sebuah pengembangan dalam pembelajaran bahasa Arab. Adapun tujuannya: (1) untuk mengetahui desain dan implementasi mobile learning sebagai upaya peningkatan pembelajaran bahasa Arab, dan (2) mempermudah guru dan peserta didik dalam mempelajari bahasa Arab secara online.

\section{Studi Literatur Mobile Learning}

Mobile learning atau sering disingkat dengan m-learning termasuk suatu model pembelajaran yang melibatkan pesatnya kemajuan teknologi seluler yang dimanfaatkan sebagai sebuah media belajar mengajar. Media pembelajaran sering dikenal dengan istilah media pendidikan. Media pembelajaran adalah suatu perangkat ataupun perantara yang berguna untuk mempermudah berjalannya proses pembelajaran. ${ }^{18}$ Komunikasi antara guru dan peserta didik merupakan hal vital bagi berjalannya proses pembelajaran. Pada proses komunikasi antara guru dengan peserta didik dibutuhkan profesionalisme dan kemampuan khusus dari guru untuk dapat mengemasnya secara efektif, aktif, dan menyenangkan sehingga peserta didik merasa nyaman dalam proses pembelajaran yang dapat berpengaruh terhadap hasil dari pembelajarannya.

Gagne dan Briggs berpendapat bahwa yang termasuk dari media pembelajaran adalah alat yang secara fisik dipergunakan dalam penyampaian materi pembelajaran yaitu buku, VCD, LCD, grafik, gambar, dan lainnya. Jadi media dapat dikatakan pula salah satu dari komponen pembelajaran yang mengandung materi pembelajaran yang diterapkan pada siswa yang berfungsi merangsang pola pikir pembelajaran siswa secara lebih mendalam. ${ }^{19}$ Sedangkan mobile learning merupakan suatu terobosan pembelajaran dimana ia memanfaatkan kecanggihan teknologi gadget yang hampir dimiliki oleh setiap orang di era sekarang ini. Keegan menuturkan bahwa mobile learning merupakan salah satu penyelenggara pendidikan yang memanfaatkan PDA, pocket PCs, serta telepon seluler. ${ }^{20}$

Mobile Learning adalah suatu model pembelajaran yang mengkonstruksikan beberapa perangkat bergerak sehingga peserta didik dapat mengakses materi

18 Muslih Muslih, "Pemanfaatan Media Pembelajaran Berbasis ICT pada Lembaga Pendidikan Non-Formal TPQ," Dimas: Jurnal Pemikiran Agama untuk Pemberdayaan 16, no. 2 (2016): 215, https://doi.org/10.21580/dms.2016.162.1090.

${ }^{19}$ Abdul Wahab Rosyidi, Media Pembelajaran Bahasa Arab (Malang: UIN Malang Press, 2009), 26.

${ }^{20}$ Agah Tugrul Korucu dan Ayse Alkan, "Differences between M-Learning (Mobile Learning) and eLearning, Basic Terminology and Usage of m-Learning in Education," Procedia - Social and Behavioral Sciences 15 (2011): 1925, https://doi.org/10.1016/j.sbspro.2011.04.029. 
pembelajaran, petunjuk pembelajaran, dan aplikasi pembelajaran tanpa adanya pembatasan ruang dan waktu belajar. ${ }^{21}$ Berbagai manfaat bisa didapatkan peserta didik dan pendidik dalam menggunakan sistem pembelajaran ini. Peserta didik dapat berkomunikasi dengan pendidik berkaitan dengan pembelajaran ataupun kesulitan pembelajaran secara mudah dan cepat. Peserta didik juga dapat belajar secara mandiri, tanpa bergantung sepenuhnya kepada pendidik karena mobile learning biasanya dilengkapi dengan materi, soal, tes, serta berbagai fitur lainnya yang dapat diakses secara mandiri oleh peserta didik. Pendidik juga dapat memantau peserta didik kapan saja dan dimana saja tanpa harus selalu di sampingnya. Pendidik dapat dengan mudah memberikan penilaian karena dibantu dengan penilaian otomatis dari tugas yang telah dikerjakan oleh siswa. ${ }^{22}$

\section{Google Classroom}

Kesempatan dan peluang terbuka lebar bagi para pendidik untuk dapat meningkatkan serta mengembangkan kompetensinya khususnya kompetensi profesionalnya melalui penggunaan berbagai piranti teknologi informasi dan komunikasi di dalam proses pembelajaran. ${ }^{23}$ Penggunaan teknologi dalam upaya memecahkan berbagai problematika pembelajaran diharapkan dapat mengoptimalkan peran pendidik dalam hal memanfaatkan kecanggihan teknologi dalam dunia pendidikan. Berbagai aplikasi dan platform ditawarkan dalam berbagai bidang, termasuk bidang pendidikan. Bidang pendidikan rupanya menjadi salah satu bidang yang mendapat perhatian terkait penyediaan berbagai platform dan aplikasi penunjang pembelajaran. Salah satu media yang dapat dimanfaatkan dalam mengoptimalkan pembelajaran dan sebagai sarana untuk memanfaatkan teknologi dalam pembelajaran adalah google classroom. ${ }^{24}$

Google Classroom merupakan piranti yang diciptakan Google.inc yang menyediakan sebuah kelas virtual. Media ini memanfaatkan jaringan internet dan dalam pengaplikasiannya menggunakan komputer ataupun smartphone. Google Classroom adalah salah satu sub-produk dari Google For Education yang memfokuskan produk-produknya bagi kemajuan dunia pendidikan. Google For Education berusaha membantu memecahkan berbagai masalah dalam dunia pendidikan khususnya dalam layanan pembelajaran. Google For Education

\footnotetext{
${ }^{21}$ Bambang Warsita, "Mobile Learning Sebagai Model Pembelajaran Yang Efektif Dan Inovatif," Jurnal Teknodik 14, no. 1 (2010): 62-73, https://doi.org/10.32550/teknodik.v14i1.452.

${ }^{22}$ Wiwin Hartanto, "Inovasi Media Pembelajaran Mobile Learning (M-Learning) : Implementasi, Efisiensi, Efektivitas, Dan Daya Tarik," Jurnal Pendidikan Ekonomi: Jurnal IImiah IImu Pendidikan, IImu Ekonomi Dan Ilmu Sosial 2 (2016): 404, https://jurnal.unej.ac.id/index.php/JPE/article/view/7447.

${ }^{23}$ John Anderson dan Robert McCormick, "Ten Pedagogic Principles for E-Learning" (Brussels: European Schoolnet, 2006), 10-15, http://insight.eun.org/ww/en/pub/insight/thematic_dossiers/qualitycriteria.htm.

24 Sukmawati Sukmawati, "Implementasi Pemanfaatan Google Classroom Dalam Proses Pembelajaran Online Di Era Industri 4.0," Jurnal Kreatif Online 8, no. 1 (2020): 39-46, http://jurnal.untad.ac.id/jurnal/index.php/JKTO/article/view/15680.
} 
memiliki beberapa layanan seperti: Google Classroom, Google Mail, Google Drive, Google Calender, Google Doc, Google Sheets, Google Slides, dan Google Sites. ${ }^{25}$

Google Classroom merupakan salah satu layanan berbasis e-learning yang disediakan oleh Google. Layanan ini sengaja didesain oleh oleh Google sebagai sarana pendidikan yang dapat membantu tenaga pendidik dan peserta didik dapat bekerja secara maksimal dan pengumpulan tugas secara paperless. ${ }^{26}$ Google Classroom merupakan jawaban bagi permasalahan keterbatasan ruang dan waktu dalam pembelajaran langsung, selain itu juga layanan ini mempermudah pendidik untuk dapat mengevaluasi tugas atau kegiatan peserta didik secara otomatis dan rapi. Proses pembelajaran secara daring yang banyak dicemaskan oleh pendidik dan orang tua adalah sulitnya melakukan pengawasan atau pemantauan, melalui aplikasi ini pendidik dan orang tua dapat memantau peserta didik dalam belajarnya terutama kedisiplinannya dalam mengumpulkan tugas atau saat berdiskusi. Berbagai fitur yang ditawarkan oleh Google Classroom dinilai efektif untuk membantu memecahkan berbagai permasalahan dalam pembelajaran serta menciptakan pembelajaran yang lebih efektif dan efisien. ${ }^{27}$

Sebagai sebuah layanan terbaik Google, perusahaan ini membekali produknya dengan berbagai kelebihan dan kemudahan baik dalam penggunaannya maupun dalam instalasinya. Kelebihan itu adalah: menghemat waktu, sistem berbasis Cloud sehingga data kita aman, fleksibel, serta gratis tanpa berbayar dan tentunya mobile friendly. Berbagai kelebihan inilah yang membuat konsumen terutama kalangan pendidik melirik layanan ini. ${ }^{28}$ Google Classroom juga memberikan layanan bagi guru untuk membuat dan membagikan materi pembelajaran, pengumpulan tugas, melakukan evaluasi serta umpan balik kepada peserta didik. ${ }^{29}$

\section{Quizizz}

Quizizz adalah salah satu aplikasi pendidikan yang berbasis game atau turnamen. Jiwa kompetitif dan motivasi peserta didik dapat meningkat melalui aplikasi ini. Melalui aplikasi ini peserta didik dapat lebih bersemangat untuk berkompetisi menjadi lebih baik lagi dalam pembelajaran, selain itu dikarenakan

25 Buaddin Hasan, "Pemanfaatan Google Classroom Dalam Mata Kuliah Menggunakan Media Video Screencast O-Matic," Widya Wacana: Jurnal Ilmiah 15, no. 1 (2020): 9-15, https://doi.org/10.33061/j.w.wacana.v15i1.3484.

26 Siti Qomariah, Nursobah, dan Siti Lailiyah, "Implementasi Pemanfaatan Google Classroom untuk pembelajaran di Era Revolusi 4.0," SINDIMAS 1 (2019): 227, http://sisfotenika.stmikpontianak.ac.id/index.php/sindimas/article/view/573.

27 Erfin Nurfalah, "Optimalisasi E-Learning Berbasis Virtual Class dengan Google Classroom sebagai Media Pembelajaran Fisika," Physics Education Research Journal 1, no. 1 (2019): 46-55, https://doi.org/10.21580/perj.2019.1.1.3977.

${ }^{28}$ Shampa Iftakhar, "Google Classroom: What Works and How?," Journal of Education and Social Science (JESOC) 3 (2016): 12-18, https://jesoc.com/wp-content/uploads/2016/03/KC3_35.pdf.

${ }^{29}$ Delsika Pramata Sari dkk., "Pelatihan Penggunaan Google Classroom untuk Mengoptimalkan Proses Pembelajaran," Bubungan Tinggi: Jurnal Pengabdian Masyarakat 1, no. 2 (2020): 56-60, https://doi.org/10.20527/btjpm.v1i2.1785. 
aplikasi ini berbasis turnamen maka peserta didik merasa tertantang untuk menyelesaikan soal-soal yang diberikan untuk menjadi pemenang dalam turnamen tersebut. $^{30}$ Amornchewin menjelaskan Quizizz adalah sebuah aplikasi dimana pendidik dapat membuat -kuis interaktif multiplayer" yang dapat diakses melalui tablet, smartphone, maupun personal computer. ${ }^{31}$

Tidak seperti aplikasi pendidikan lainnya, terdapat keunikan tersendiri pada aplikasi Quizizz. Keunikan tersebut adalah pada aplikasi ini memiliki karakteristik game seperti adanya avatar, meme, tema, serta musik yang mengiringi proses pembelajaran. Peserta didik dapat mengambil kuis pada saat yang sama kemudian setelah selesai ia dapat melihat posisinya pada nomor yang tertera di papan peringkat. Instruktur atau pendidik dapat memantau bagaimana jalannya aplikasi ini mulai dari tahap persiapan, jumlah peserta, sampai dengan tahap pelaporan yang berfungsi untuk mengevaluasi kinerja peserta didik. ${ }^{32}$

Cara kerja aplikasi ini cukup mudah, yaitu pendidik membuat kuis untuk dapat dikerjakan oleh peserta didik terlebih dahulu di laman Quizizz. Setelah soal siap dan waktu untuk pengerjaan soal sudah ditentukan, maka pendidik dapat mempersilahkan peserta didik untuk login ke alamat quizizz.com ataupun melalui aplikasi yang dapat didownload di playstore. Maupun app-store. Peserta didik yang sudah login, maka mereka diharuskan join menggunakan kode yang sudah dibagikan oleh pendidik. Mereka kemudian memasukkan nama dan selanjutnya mengerjakan sesuai waktu yang telah ditentukan. Peserta didik dapat melihat pertanyaan pada smartphone mereka masing-masing tahu melalui komputer tanpa harus menggunakan LCD Proyektor. ${ }^{33}$

Salah satu fitur unik lainnya dari aplikasi ini adalah aplikasi ini akan memberikan data statistik mengenai kinerja peserta didik dan dapat melacak jumlah peserta didik yang mampu menjawab pertanyaan yang dibuat. Data-data statistik ini kemudian dapat didownload dalam bentuk Spreadsheet pada Microsoft Excel. Selanjutnya, untuk memberikan tugas evaluasi dengan batasan waktu yang telah ditentukan dapat diberikan pendidik kepada peserta didik melalui fitur pekerjaan rumah.

30 Sri Wilda Albeta, Nofianti Nofianti, dan Sri Rahmandani, "Peranan Turnamen Berbasis ICT Dengan Aplikasi Quizizz Terhadap Pembelajaran Kimia," Jurnal Pendidikan Kimia Universitas Riau 5, no. 1 (2020): 11-15, https://doi.org/10.33578/jpk-unri.v5i1.7778.

${ }^{31}$ Ratchadaporn Amornchewin, "The Development of SQL Language Skills in Data Definition and Data Manipulation Languages Using Exercises with Quizizz for Students' Learning Engagement," IJIE (Indonesian Journal of Informatics Education) 2, no. 2 (2019): 85-90, https://doi.org/10.20961/ijie.v2i2.24430.

32 Leony Sanga Lamsari Purba, “Peningkatan Konsentrasi Belajar Mahasiswa Melalui Pemanfaatan Evaluasi Pembelajaran Quizizz Pada Mata Kuliah Kimia Fisika I," Jurnal Dinamika Pendidikan 12, no. 1 (2019): 29-39, http://ejournal.uki.ac.id/index.php/jdp/article/view/1028.

${ }^{33}$ Yanawut Chaiyo dan Ranchana Nokham, "The Effect of Kahoot, Quizizz and Google Forms on the Student's Perception in the Classrooms Response System," International Conference on Digital Arts, Media and Technology (ICDAMT), 2017, 178, https://doi.org/10.1109/ICDAMT.2017.7904957. 


\section{Metode Penelitian}

Jenis penelitian ini merupakan penelitian Eksperimen dengan model desain penelitian ini adalah The One Group Pretest-Posttest Design. Severin dan Tankard mengemukakan pendapatnya terkait penelitian eksperimen. Menurut keduanya, salah satu keuntungan dari digunakannya metode eksperimen dalam suatu penelitian adalah adanya kendali tangan dari peneliti serta ketepatan logika peneliti yang terkandung di dalamnya. ${ }^{34}$ Kerlinger menganggap bahwa metode eksperimen adalah sebuah penelitian ilmiah dimana para peneliti dapat memanipulasi ataupun mengontrol satu atau lebih variabel bebas serta melakukan pengamatan terhadap variabel-variabel terikat untuk dapat menemukan variasi yang kemunculannya bersamaan dengan manipulasi pada variabel bebas tersebut. ${ }^{35}$

One-Group Pretest-Posttest Design dilakukan kepada kelompok yang menjadi subjek penelitian, kemudian diberikan treatment atau perlakuan lalu dilakukan posttest dengan menggunakan pengukuran yang sama. Adapun kelompok yang dikenai pretest dan posttest merupakan kelompok yang sama. Pretest ini dilakukan dengan memberikan soal pemahaman bab yang akan dipelajari sedangkan treatment yang diberikan berupa penggunaan Google Classroom dan Quizizz kemudian setelahnya diberikan posttest dengan pemberian berupa soal-soal mengenai materi yang dipelajari yang dijawab melalui aplikasi Quizizz yang sama pada saat pemberian pretest.

Penelitian ini dilakukan selama bulan Januari-Agustus 2020. Subjek dari penelitian ini adalah pembelajaran Bahasa Arab yang di lakukan di MA Nurul Ulum Kota Gajah dan MA Ma'arif 9 Kota Gajah. Dalam upaya menghimpun data pada proses penelitian didapatkan melalui observasi, wawancara, angket dan tes.

\section{Hasil dan Pembahasan}

\section{Pembelajaran Bahasa Arab dengan mobile learning}

Hasil observasi awal sebelum diterapkan mobile learning, keadaan belajar mengajar pada kedua sekolah tersebut masih menggunakan model pembelajaran yang diterapkan oleh pengajar secara umum yang terpaku pada model konvensional yaitu normatif (doktriner) dan dogmatis. Guru belum mengembangkan bahan pengajaran dengan memanfaatkan media pembelajaran. Begitu pun siswa masih kurang responsif dan cenderung hanya pasif akibat kurangnya motivasi belajar dan penerapan model pembelajaran yang tradisional. Dalam penyampaian materi di kelas, guru juga masih menggunakan metode

\footnotetext{
${ }^{34}$ Werner J. Severin dan James W. Tankard Jr., Communication Theories: Origins, Methods and Uses in the Media (London: Addison Wesley Longman, 2001), 43.

${ }^{35}$ Fred Kerlinger, Foundations of Behavioral Research 2nd Second Edition (New York: Rinehart and Winston, 1973), 315.
} 
ceramah. Sehingga intensitas hubungan guru dengan siswa kurang terlaksana secara maksimal karena teacher center.

Di samping hal tersebut guru merasa pada kondisi dilematis karena alokasi waktu, yakni tidak tercukupinya jam pelajaran terlebih pada masa pandemi covid 19. Pembelajaran bahasa Arab yang diterapkan kurang maksimal karena terbatas waktu dan tempat. Sedangkan buku paket yang digunakan kurang relevan dengan realitas, kurang kontekstual dan kurang interaktif.

Pada kelompok kontrol guru mengajar dengan menerapkan model pembelajaran secara konvensional. Yaitu memakai metode ceramah dan tanya jawab dengan tanpa memakai modul. Hal tersebut dirasa kurang efektif dalam meningkatkan pemahaman siswa, karena dalam pembelajaran konvensional mengakibatkan kebanyakan anak didik berada pada posisi statis dan menjadi pasif, kurang antusias serta merasa bosan. Pembelajaran terasa kurang dinamis, terkesan monoton sehingga mengakibatkan kurangnya perhatian siswa pada materi yang disampaikan oleh guru.

Sedangkan pada kelompok eksperimen guru menggunakan mobile learning untuk menunjang pembelajaran. Mobile learning yang juga dikenal dengan istilah m-learning merupakan cara baru untuk mengakses konten materi pembelajaran dengan bantuan perangkat mobile sehingga proses pembelajaran dapat diakses secara berkelanjutan. Hal tersebut dapat dilakukan menggunakan perangkat seperti ponsel, laptop, atau tablet. Melalui mobile learning, pembelajaran dapat dilaksanakan di manapun dan kapanpun. Dengan kemajuan mobile learning, sistem pendidikan berubah.

Contoh pembelajaran mobile learning adalah menawarkan materi pembelajaran dalam bentuk teks, video, dan audio. Peserta didik dapat diberikan tugas setelah selesai menonton video dari guru atau dosen yang telah ditaruh secara online (asynchronous learning). Pendidik juga dapat menggunakan perangkat mobile untuk meningkatkan interaksi. Misalnya dengan memanfaatkan forum diskusi online atau mengadaptasi gamification dengan menyelenggarakan kuis di mana peserta dapat menjawab langsung dengan perangkatnya masingmasing.

Sebelum memulai penggunaan mobile learning dalam kelas, dipastikan terlebih dahulu siswa untuk mempersiapkan alat dan koneksi internet serta halhal lainnya yang dibutuhkan. Dalam penelitian ini menggunakan Google Classroom dan Quizizz sebagai platform penunjang. Yang mana kedua aplikasi tersebut bisa dikombinasikan sehingga didapatkan pembelajaran yang efisien serta seluruh data dapat dihimpun pada kedua aplikasi tersebut.

Jika diperhatikan dari nilai rata-rata kelas sebenarnya hasil belajar untuk mobile learning berbasis android belum menunjukkan tingkat efektifitas yang signifikan dari hasil belajar. Karena rata-rata kelas dengan eksperimen tidak berbeda jauh dengan kelas control. Demikian juga dari jumlah siswa yang tuntas 
belajar, siswa yang tuntas belajar kelas eksperimen adalah siswa yang menuntaskan $60 \%$ ke atas. Untuk MA Ma'arif yang mencapai ketuntasan minimal adalah 10 peserta didik dari 17 peserta didik (59,8\%). Sedangkan untuk kelas control yang mencapai ketuntasan minimal adalah nilai 60 ke atas yaitu berjumlah 11 peserta didik dari 15 peserta didik (73\%). Sedangkan untuk MA Nurul Ulum Kotagajah jumlah yang mencapai ketuntasan minimal pada kelompok eksperimen adalah 8 peserta didik dari 13 peserta didik (61,5\%) sedangkan yang kelompok control adalah 13 dari 17 peserta didik (76,5\%).

Pembelajaran bahasa Arab dengan media mobile learning berbasis android pada Madrasah Aliyah Ma'arif 9 dan Madrasah Aliyah Nurul Ulum Kotagajah Lampung Tengah secara kebahasaan memang belum menunjukkan adanya efektivitas yang signifikan, namun secara non kebahasaan menunjukkan adanya kontribusi positif terhadap motivasi peserta didik dengan beberapa indikator berikut: Pertama, tekun dalam mengerjakan tugas. Mereka tetap semangat dan antusias selama proses pembelajaran. Seakan tidak ada bosan, semakin penasaran dengan tugas-tugas yang berpacu dengan waktu. Kedua, tidak puas dengan hasil yang diperoleh. Mereka memang tampak bahagia dengan tertawa lepas ketika jawabannya benar, dan mengaduh sedih jika jawabannya salah. Namun tetap ingin mencoba untuk mengerjakan tugas yang lain lagi. Ketiga, lebih suka fokus untuk bekerja sendiri. Dengan media ini peserta didik tidak terpikir untuk mencontoh teman, karena waktu terus berjalan, dan akan berganti soal secara otomatis jika waktunya habis. Di samping itu kecepatan dalam menjawab juga berpengaruh terhadap penilaian. Namun mereka juga rileks tanpa ada rasa berat ataupun tertekan. Hal ini dapat dilihat dari kegembiraan mereka dalam mengerjakan tugastugas. Di antara mereka terkadang ada yang sampai tertawa lepas, menepuk-nepuk dada, menepuk jidat, menggoyang- goyangkan kaki sebagai ekspresi gembira ataupun sedih sedih karena hasil yang diperoleh.

\section{Keterbatasan Penelitian}

Penelitian yang dilakukan ini tentu secara sadar masih terdapat adanya beberapa kekurangan dan keterbatasan dalam pelaksanaannya, oleh karenanya dipandang perlu untuk disampaikan agar menjadi pertimbangan seperlunya. Adapun beberapa keterbatasan yang ada dalam penelitian ini adalah sebagai berikut: (1) Pada pertengahan proses penelitian ini, yaitu tepatnya pada bulan Maret tahun 2020, Indonesia saat itu mulai terkena wabah virus Covid-19. Karenanya akses dan pencarian data cukup terhambat. Dalam beberapa kesempatan siswa masih dalam proses belajar dari rumah. Sedangkan seiring berjalannya waktu proses pembelajaran dilakukan dengan sistem pembagian waktu bagi sebagian siswa ada yang hadir secara luring di sekolah dan sebagian belajar dari rumah karena pihak sekolah harus mengikuti instruksi dari pimpinan daerah masing-masing. (2) Guru dan siswa masih belum dapat menyesuaikan diri 
karena situasi kondisi pandemi yang datang secara tiba-tiba. Sehingga ada beberapa peserta didik yang sulit dikendalikan dalam proses pembelajaran yang berlangsung secara daring. Peserta didik belum terbiasa mengikuti pembelajaran dengan menggunakan mobile learning. Sehingga terdapat beberapa siswa yang tidak bekerja secara maksimal. (3) Sulitnya jaringan internet yang digunakan serta kendala teknis lainnya, mengakibatkan terhambatnya beberapa proses percobaan mobile learning dalam proses penelitian.

\section{Kesimpulan}

Dari pembahasan yang telah dipaparkan di atas, dapat disimpulkan bahwa pengembangan mobile learning berbasis android masih belum menunjukkan hasil dan efektivitas terhadap hasil belajar. Namun efektif dalam menumbuhkan motivasi dan minat belajar bahasa Arab. Hal tersebut tersebut ada kemungkinan dipengaruhi oleh beberapa faktor, yaitu koneksi internet yang kurang memadai dan belum familiernya peserta didik dengan media mobile learning, serta tidak semua siswa memiliki handphone android dengan spesifikasi yang layak untuk pembelajaran secara daring. Berdasarkan simpulan tersebut, perlu adanya kegiatan yang intens untuk pelatihan pengembangan mobile learning dalam pembelajaran bahasa Arab, serta adanya penelitian yang berkesinambungan.

\section{Ucapan Terima Kasih}

Peneliti mengucapkan rasa terima kasih sebanyak-banyaknya kepada Lembaga Penelitian dan Pengabdian Masyarakat (LPPM) Institut Agama Islam Negeri Metro yang telah mempercayakan kepada tim peneliti untuk dapat berkontribusi dalam penelitian Litapdimas Tahun 2020 pada klaster interdisipliner; sehingga dapat diselesaikan dan menghasilkan luaran artikel jurnal ilmiah berikut ini.

\section{Daftar Pustaka}

Albeta, Sri Wilda, Nofianti Nofianti, dan Sri Rahmandani. "Peranan Turnamen Berbasis ICT Dengan Aplikasi Quizizz Terhadap Pembelajaran Kimia." Jurnal Pendidikan Kimia Universitas Riau 5, no. 1 (2020): 11-15. https://doi.org/10.33578/jpk-unri.v5i1.7778.

Amirullah, Gufron, dan Restu Hardinata. "Pengembangan Mobile Learning Bagi Pembelajaran." JKKP (Jurnal Kesejahteraan Keluarga Dan Pendidikan) 4, no. 02 (2017): 97. https://doi.org/10.21009/JKKP.042.07.

Amornchewin, Ratchadaporn. "The Development of SQL Language Skills in Data Definition and Data Manipulation Languages Using Exercises with Quizizz for Students' Learning Engagement." IJIE (Indonesian Journal of Informatics $\begin{array}{lllll}\text { Education) } & 2, & \text { no. } & 2 & \text { (2019): }\end{array}$ https://doi.org/10.20961/ijie.v2i2.24430. 
Anderson, John, dan Robert McCormick. "Ten Pedagogic Principles for E-Learning," 10-15. Brussels: European 2006. http://insight.eun.org/ww/en/pub/insight/thematic_dossiers/qualitycrite ria.htm.

Bhakti, Andri Kusuma, Firdaus Solihin, dan Fitri Damayanti. "Pengembangan MLearning Bahasa Arab Berbasis LTSA Dengan Pendekatan ADDIE." Jurnal $\begin{array}{lllll}\text { Simantec } & 6, & \text { no. } & 2 & \text { (2017): }\end{array}$ https://journal.trunojoyo.ac.id/simantec/article/view/3809.

Chaiyo, Yanawut, dan Ranchana Nokham. "The Effect of Kahoot, Quizizz and Google Forms on the Student's Perception in the Classrooms Response System." International Conference on Digital Arts, Media and Technology (ICDAMT), 2017, 178. https://doi.org/10.1109/ICDAMT.2017.7904957.

Fransiska, Fredina, dan Zaim Elmubarok. "Efektivitas Metode Reading Guide Terhadap Keterampilan Membaca Bahasa Arab Siswa Kelas XI IPS MAN Demak." Lisanul Arab: Journal of Arabic Learning and Teaching 4, no. 1 (2015). https://journal.unnes.ac.id/sju/index.php/laa/article/view/7634.

Hartanto, Wiwin. "Inovasi Media Pembelajaran Mobile Learning (M-Learning) : Implementasi, Efisiensi, Efektivitas, Dan Daya Tarik." Jurnal Pendidikan Ekonomi: Jurnal Ilmiah Ilmu Pendidikan, Ilmu Ekonomi Dan Ilmu Sosial 2 (2016): 404. https://jurnal.unej.ac.id/index.php/JPE/article/view/7447.

Hasan, Buaddin. "Pemanfaatan Google Classroom Dalam Mata Kuliah Menggunakan Media Video Screencast O-Matic." Widya Wacana: Jurnal $\begin{array}{lllll}\text { Ilmiah } & 15, & \text { no. } & 1 & \text { (2020): }\end{array}$ https://doi.org/10.33061/j.w.wacana.v15i1.3484.

Hasani, Zhul Fahmy. "Penerapan Metode Imla' Untuk Meningkatkan Keterampilan Menulis Siswa Kelas VIIC MTs Muhammadiyah 02 Pemalang." Lisanul Arab: Journal of Arabic Learning and Teaching 2, no. 1 (2013): 57-64. https://journal.unnes.ac.id/sju/index.php/laa/article/view/2564.

Hidayat, Nandang Sarip. "Problematika Pembelajaran Bahasa Arab." An-Nida' 37, no. 1 (2012): $\quad$ 82-88. suska.ac.id/index.php/Anida/article/view/315.

Iftakhar, Shampa. "Google Classroom: What Works and How?" Journal of Education and Social Science (JESOC) 3 (2016): 12-18. https://jesoc.com/wpcontent/uploads/2016/03/KC3_35.pdf.

Jauhari, Qomi Akid. "Pembelajaran Maharah Istima Di Jurusan PBA UIN Maulana Malik Ibrahim Malang." Tarbiyatuna: Jurnal Pendidikan Ilmiah 3, no. 1 (2018):

129. http://ejournal.kopertais4.or.id/mataraman/index.php/tarbiyatuna/article /view/3440.

Kerlinger, Fred. Foundations of Behavioral Research 2nd Second Edition. New York: Rinehart and Winston, 1973. 
Korucu, Agah Tugrul, dan Ayse Alkan. "Differences between M-Learning (Mobile Learning) and e-Learning, Basic Terminology and Usage of m-Learning in Education." Procedia - Social and Behavioral Sciences 15 (2011): 1925. https://doi.org/10.1016/j.sbspro.2011.04.029.

Mujib, Fathul, dan Nailur Rahmawati. Metode Permainan-Permainan Edukatif Dalam Belajar Bahasa Arab. Yogyakarta: Diva Press, 2011.

Muslih, Muslih. "Pemanfaatan Media Pembelajaran Berbasis ICT pada Lembaga Pendidikan Non-Formal TPQ." Dimas: Jurnal Pemikiran Agama untuk $\begin{array}{lllll}\text { Pemberdayaan } & 16, & & \end{array}$ https://doi.org/10.21580/dms.2016.162.1090.

Republika Online. "Nadiem: Belajar Di Rumah Perlu Dibuat Prosedur Khusus," 21 Maret 2020. https://republika.co.id/share/q7hplp430.

Novantara, Panji. "Implementasi dan Efektifitas Mobile Learning dengan Menggunakan Metode Synchronous dan Asynchronous Learning pada Pembelajaran Bahasa Inggris di Universitas Kuningan Berbasis Android." Buffer Informatika 3, no. 1 (2017): 22-27. https://doi.org/10.25134/buffer.v3i1.932.

Nur, Hastang. "Penerapan Metode Muhadatsah Dalam Meningkatkan Hasil Belajar Maharah Kalam Peserta Didik." Lentera Pendidikan: Jurnal Ilmu Tarbiyah Dan Keguruan 20, no. 2 (2017): 177. https://doi.org/10.24252/lp.2017v20n2i4.

Nurfalah, Erfin. “Optimalisasi E-Learning Berbasis Virtual Class dengan Google Classroom sebagai Media Pembelajaran Fisika." Physics Education Research Journal $1, \quad$ no. 11 (2019): https://doi.org/10.21580/perj.2019.1.1.3977.

Ozdamli, Fezile, dan Nadire Cavus. "Basic Elements and Characteristics of Mobile Learning." Procedia - Social and Behavioral Sciences 28 (2011): 937-42. https://doi.org/10.1016/j.sbspro.2011.11.173.

Praseptiawan, Mugi, Dadan Sujana, dan Muhamad Djuanda. "Pengembangan Mobile Learning (M-Learning) STKIP Setiabudhi Sebagai Daya Dukung Pembelajaran Mahasiswa." Produktif: Jurnal Ilmiah Pendidikan Teknologi Informasi 2018 (2018): 18. https://journal.umtas.ac.id/index.php/produktif/article/view/212.

Purba, Leony Sanga Lamsari. "Peningkatan Konsentrasi Belajar Mahasiswa Melalui Pemanfaatan Evaluasi Pembelajaran Quizizz Pada Mata Kuliah Kimia Fisika I." Jurnal Dinamika Pendidikan 12, no. 1 (2019): 29-39. http://ejournal.uki.ac.id/index.php/jdp/article/view/1028.

Qomariah, Siti, Nursobah, dan Siti Lailiyah. "Implementasi Pemanfaatan Google Classroom untuk pembelajaran di Era Revolusi 4.0." SINDIMAS 1 (2019): 227. 
http://sisfotenika.stmikpontianak.ac.id/index.php/sindimas/article/view/ 573.

Rahayu, Widya Adhariyanty, dan Suastika Yulia Riska. "Developing English Vocabulary Learning Game." Jurnal Cakrawala Pendidikan 37, no. 1 (2018): 85-96. https://journal.uny.ac.id/index.php/cp/article/view/15965.

Rosyidi, Abdul Wahab. Media Pembelajaran Bahasa Arab. Malang: UIN Malang Press, 2009.

Sangid, Akhmad, dan Mohammad Muhib. "Strategi Pembelajaran Muhadatsah." Tarling: Journal of Language Education 2, no. 1 (2018): 1-22. https://doi.org/10.24090/tarling.v2i1.2226.

Sari, Delsika Pramata, R. Ati Sukmawati, Harja Santana Purba, Dimas Maulana Muhammad, dan Syahril Hanla Azis. "Pelatihan Penggunaan Google Classroom untuk Mengoptimalkan Proses Pembelajaran." Bubungan Tinggi: Jurnal Pengabdian Masyarakat 1, no. 2 (2020): 56-60. https://doi.org/10.20527/btjpm.v1i2.1785.

Septian, Hilman, Eka Wahyu Hidayat, dan Alam Rahmatulloh. "Aplikasi Pengenalan Bahasa Arab dan Inggris untuk Anak-Anak Berbasis Android.” Jurnal Online $\begin{array}{lllll}\text { Informatika } 2, & \text { no. } & 2 & \text { (2018): }\end{array}$ https://doi.org/10.15575/join.v2i2.100.

Setyosari, Punaji. "Menciptakan Pembelajaran Yang Efektif Dan Berkualitas." JINOTEP (Jurnal Inovasi Dan Teknologi Pembelajaran): Kajian Dan Riset Dalam Teknologi Pembelajaran 1, no. 1 (13 Desember 2017): 20-30. https://doi.org/10.17977/um031v1i12014p020.

Severin, Werner J., dan James W. Tankard Jr. Communication Theories: Origins, Methods and Uses in the Media. London: Addison Wesley Longman, 2001.

Sukmawati, Sukmawati. "Implementasi Pemanfaatan Google Classroom Dalam Proses Pembelajaran Online Di Era Industri 4.0." Jurnal Kreatif Online 8, no. 1 (2020): 39-46. http://jurnal.untad.ac.id/jurnal/index.php/JKTO/article/view/15680.

Ugale, Chetan B, Akshay S Nigal, Ramdas Shinde, Mayuri Metkar, dan U B Pawar. "Mobile Learning Application With Online Query Support." IJMTER (International Journal of Modern Trends in Engineering and Research) 02, no. 10 (2015): 239. https://www.ijmter.com/published-papers/volume2/issue-10/mobile-learning-application-with-online-query-support/.

Warsita, Bambang. "Mobile Learning Sebagai Model Pembelajaran Yang Efektif Dan Inovatif." Jurnal Teknodik 14, no. 1 (2010): 62-73. https://doi.org/10.32550/teknodik.v14i1.452. 
